\title{
Influence of Bone Quality on the Use of Implant Prostheses with Intermediate Pontic: Three- dimensional Finite Element Method
}

\author{
Marcelo Bighetti Toniollo ${ }^{1}$ Andrea Sayuri Silveira Dias Terada ${ }^{1}$ Jair Pereira de Melo Júnior ${ }^{2}$ \\ Cláudio Rodrigues Rezende Costa ${ }^{1}$ Diogo Henrique Vaz de Souza ${ }^{1}$
}

\footnotetext{
${ }^{1}$ Department of Odontology, Dental School of Rio Verde, University of Rio Verde (FORV/UniRV), Rio Verde - GO, Brazil

2 Department of Biophysics, Medicine School of Rio Verde, University of Rio Verde (FAMERV/UniRV), Rio Verde - GO, Brazil
}

\begin{abstract}
Address for correspondence Marcelo Bighetti Toniollo, MSc, PhD, Dental School of Rio Verde, University of Rio Verde (FORV/UniRV), Fazenda Fontes do Saber, Setor Universitário, Rio Verde - GO, 75.909-781, Brazil (e-mail: marcelo.toniollo@unirv.edu.br).
\end{abstract}

Dent J Adv Stud 2021;9:151-156.

\begin{abstract}
Objective The present study aimed to observe the differences in the dissipation of the main minimum stresses with the use of a fixed pontic partial prosthesis supported by two regular length implants in cortical and medullary bone tissues of different qualities.

Materials and Methods Experimental groups were as follows: QI (two regular length implants with fixed pontic partial prosthesis and bony qualities consistent with type I), QII (identical to QI, with bony qualities consistent with type II), and QIII (identical to QI, with bony qualities consistent with type III). All the groups were developed and analyzed in virtual simulation environment using AnsysWorkbench software.

Results The results showed highest stress concentrations in the region of the turns of the implants, especially in the apical region surrounding the implants and most notably in those positioned in the posterior region, supporting the molars. In addition, comparing the cortical bone among the groups, the results revealed increasing levels of stress in the order of QI, QII, and QIII. Comparing the medullary bone among the

Keywords

- fixed partial denture

- finite element analysis

- bone-implant interface groups, the results revealed increasing levels of stress in the order of QIII, QII, and QI. Conclusion It was concluded that greater stress disparity occurred in the comparison between groups QI and QIII. There was a higher TMiP in QI in the cortical bone, but considering the literature values, it would not pose risks to its physiological limits. The use of a pontic fixed partial prosthesis on two regular implants of type III bone quality may cause unfavorable physiological repercussions for the posterior implant apical medullary bone.
\end{abstract}

\section{Introduction}

Osseointegrated implants have a stable and immobile fixation with the adjacent alveolar bone, and this leads to the transfer of masticatory loads from the rehabilitative set

published online November 23, 2021
DOI https://doi.org/

10.1055/s-0041-1739508. ISSN 2321-1482. directly to the bone, which may exceed the physiological limit of the bone, causing injuries to it. ${ }^{1}$ There are conditions of anatomical limitation, for example, in which an area of three dental elements needs to be rehabilitated with only (c) 2021. Bhojia Dental College and Hospital affiliated to Himachal Pradesh University. All rights reserved.

This is an open access article published by Thieme under the terms of the Creative Commons Attribution-NonDerivative-NonCommercial-License, permitting copying and reproduction so long as the original work is given appropriate credit. Contents may not be used for commercial purposes, or adapted, remixed, transformed or built upon. (https://creativecommons.org/ licenses/by-nc-nd/4.0/)

Thieme Medical and Scientific Publishers Pvt. Ltd., A-12, 2nd Floor Sector 2, Noida-201301 UP, India 
two implants in the extremities. ${ }^{2,3}$ In this situation, the use of implant prostheses with intermediate pontic is indispensable but requires caution, since the recommendation of the literature is to use the maximum number of implants possible. $^{4-6}$ This larger amount of implants necessitates concern regarding the transmission of stresses to the structures, whether implants or biological systems, to avoid overloading and possible failures of the involved components. ${ }^{7}$

Although there is evidence in the literature about the proper functionality of implant-supported fixed prostheses, 8,9 there is general doubt among professionals in the field regarding these prostheses with intermediate pontic, and in particular, their performance and interference with worst bone quality in the set of factors involved in these biomechanics. ${ }^{10-12}$ With some fear, professionals must always act with clinical security based on scientific evidence, and there will never be an excessive number of studies that bring safety to dentists in this regard. Another important fact that this study brings is that, due to the type of methodology used (finite element method), it is possible to visualize bone behavior in a special way, since the virtual simulation reveals areas of possible stresses, which, biologically, would be difficult to obtain with other scientific approaches. Evidently, the variation in bone quality suggested in this study is somewhat demonstrative and has limitations in the clinical correlation, but allows a glimpse of how such rehabilitation would behave in different situations of supporting bone tissues.

Therefore, knowing the mechanical and biological characteristics of all the parts involved in this system is of great importance. The quantity and quality of bone tissue are important factors to be analyzed in the general health context of the individual. ${ }^{13-15}$ Studying the characteristics of bone tissue and its reflexes in functional activity is extremely complex because, in addition to the numerous factors simultaneously associated with and interfering in its dynamics, there are different qualities between individuals and even in the same organism, depending on the region that is evaluated. ${ }^{16-18}$

For this reason, it is possible to analyze such behaviors by varying bone qualities, simply and with visual results, and to quantify the developed stresses, as the finite element analysis provides, ${ }^{19}$ there have been great gains in the generation of knowledge about the subject.

Therefore, the null hypothesis of the present study is that no differences in stress dissipation with the use of a pontic fixed partial prosthesis supported by two regular length implants will be observed in cortical and medullary bone tissues of different qualities.

\section{Material and Methods}

The mean values of mandibular bone were established based on several studies, such as those mentioned in - Table 1. ${ }^{10,20-24}$ The parts used in this study, like implants and abutments (Neodent), were measured (Profile Projector - Nikon Model 6C, and Stereomicroscope - Leica Model S8AP0), so that it could have higher degree of fidelity in modeling these structures (CADs).
Table 1 Elasticity modulus and Poissońs coefficient used for bone quality variation (MPa)

\begin{tabular}{|l|l|l|}
\hline & \multicolumn{2}{|l|}{$\begin{array}{l}\text { Elasticity modulus/Poisson's } \\
\text { coefficient }\end{array}$} \\
\hline Bone & Cortical & Medullary \\
\hline Type I & $20,000 / 0.30$ & $2,000 / 0.30$ \\
\hline Type II & $13,700 / 0.30$ & $1,370 / 0.30$ \\
\hline Type III & $7,000 / 0.30$ & $700 / 0.30$ \\
\hline
\end{tabular}

An experimental model was built using AnsysWorkbench software, with dental element 34, 4-mm diameter and 11mm length implants in the 35 and 37 regions, with a Morse taper abutment prosthetic connection. The external geometric shape of the implants used is cylindrical (indication for the mandible), and the prosthetic component is a screwed abutment type, being considered " $100 \%$ bonded" contact between the Morse connections of the implant and abutment. For this purpose, and for simulation simplification, the connection was considered totally effective and passive. A three-element metalloceramic prosthesis was made on the implants with dental element 36 suspended (pontic). The cortical bone was $2 \mathrm{~mm}$ thick and positioned externally to the medullary bone.

The material used in the prosthesis infrastructure was cobalt-chrome, with feldspathic ceramic on its covering. The holes referring to the prosthetic screw entrance of the prosthesis were covered with composite resin. Dental element 34 had a periodontal ligament, pulp, dentin, and enamel. The mechanical properties of the materials were based in previously studies, ${ }^{20}$ as described in - Table 2.

From the assembled experimental model shown in - Fig. 1 (172800 nodes and 103536 elements), the mechanical characteristics of the cortical and medullary bones were then changed by changing their elasticity modulus ( - Table 1), creating the following three experimental groups of the present study:

Table 2 Mechanical properties of the materials

\begin{tabular}{|l|l|l|}
\hline Structure & $\begin{array}{l}\text { Modulus of } \\
\text { elasticity/ } \\
\text { Young (MPa) }\end{array}$ & Poisson's ratio (v) \\
\hline Pulp & 2.07 & 0.45 \\
\hline Dentine & 18,600 & 0.31 \\
\hline Enamel & 41,000 & 0.30 \\
\hline $\begin{array}{l}\text { Periodontal ligament } \\
\text { (0.25 mm) }\end{array}$ & 68.9 & 0.45 \\
\hline Mucosa (2 mm) & 19.6 & 0.30 \\
\hline Implant (Ti) & 110,000 & 0.35 \\
\hline CoCr structure & 21,8000 & 0.33 \\
\hline Resin & 7.000 & 0.20 \\
\hline Feldspathic porcelain & 82,800 & 0.35 \\
\hline
\end{tabular}




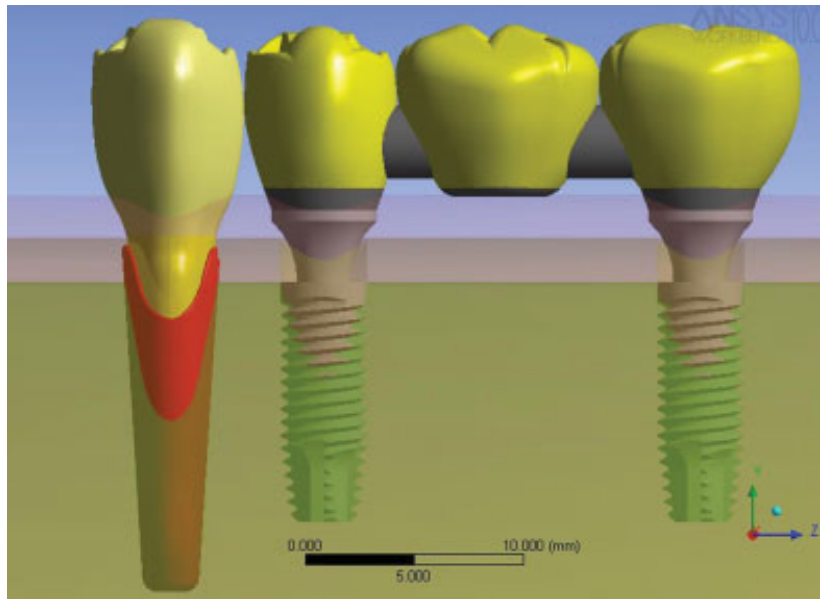

Fig. 1 Experimental group with two implants supporting fixed pontic partial prosthesis.

- QI (rehabilitation on two implants of regular length $4 \times 11 \mathrm{~mm}$ with fixed pontic partial prosthesis, cortical and medullary bone quality consistent with type I bone).

- QII (equal to QI, with cortical and medullary bone quality consistent with type II bone).

- QIII (equal to QI, with cortical and medullary bone quality consistent with type III bone).

The occlusal loads applied were defined in a total of $200 \mathrm{~N}$ in each premolar and $365 \mathrm{~N}$ in each molar in a lingualvestibular oblique direction. The location of these applied loads was positioned at the tips of the centric cusps of the prostheses, as well as in the grooves, distributed in a homogeneous and balanced way. The simulated models were considered to be homogeneous, isotropic, and linearly elastic. Such characteristics aimed at simplifying the virtual simulation environment. The interface between implants and bone was considered to be $100 \%$ osseointegrated, also under the characteristic of fully bonded. The boundary condition about the constraint condition of movement was considered as "fixed support" at the base of the experimental model.

The finite element mesh was generated, the three experimental groups were simulated, and the main minimum stress (TMiP) was analyzed, representing cooler colors, as related to the compressions developed in the cortical and medullary bone tissues.

To enable a quantitative analysis, associated with the qualitative analysis of the images, the scales generated automatically between the experimental groups were standardized among themselves. This enabled a more standardized visual analysis regarding the colors generated in the results' images for cortical and medullary bone separately.

\section{Results}

The results of the present study allowed to refute the proposed null hypothesis.
The results are shown in $\mathbf{- F i g .} \mathbf{2}$, and should be observed with a focus on the colder colors and negative values, since it was chosen with the TMiP, which represents compressive stresses.

The results showed that the highest stress concentrations occurred in the region of the turns of the implants, especially in the apical region surrounding the implants and most notably in those positioned in the posterior region, supporting the molars. In addition, comparing the cortical bone among the groups, the results revealed increasing levels of stress in the order of QI, QII, and QIII. Comparing the medullary bone among the groups, the results revealed increasing levels of stress in the order of QIII, QII, and QI. The higher elasticity modulus of type I bone generated higher cortical bone compressive TMiP. Compressive TMiP values increased from type I to type III medullary bone, which exhibits worse behavior of the lower quality bone. Under the conditions and characteristics studied, the use of a fixed pontic partial prosthesis on two regular implants generated higher stress in the apical region of the medullary bone surrounding the posterior implant.

\section{Discussion}

According to the results obtained, the null hypothesis of the present study was totally rejected, since notable stress differences were found in cortical and medullary bones, according to their quality.

In the present results, the highest compression values, in absolute numbers, were observed in cortical bone in type I bone (experimental group QI), unlike medullary bone, which were higher in type III bone (experimental group QIII).

The higher stress values in the type I cortical bone may be explained by the fact that the cortical bone has a highelasticity modulus, which eventually concentrates higher stress as its stiffness increases. Similarly, a study by Sevimay et $\mathrm{al}^{25}$ stated that cortical bone has an elasticity modulus 10 times higher than that of the medullary bone; thus, the cortical bone appears to protect the adjacent bone, and the decrease in cortical bone thickness could influence the results of rehabilitation. ${ }^{26}$

In medullary bone, because it has a lower elasticity modulus, the lower rigidity (type III bone) may have allowed higher implant intrusion, which generates higher compression. This is just an explanatory hypothesis to explain what happened, but it corroborates the results and conclusions of Meriç et al. ${ }^{27}$

The antagonism of the results obtained in the present study (as described above) between the observed stress for different cortical and medullary bone qualities is in line with the study conducted by Papavasiliou et al. ${ }^{28}$ It can be affirmed, uniting the theory described by these authors, together with the findings of the present article that cortical bone tissue represents fundamental importance to the biomechanical behavior of the system, since it presents itself as a "protector" of medullary bone tissue. For this reason, in a situation of cortical bone with higher rigidity and quality (QI), it concentrates higher stress compared with the lower 


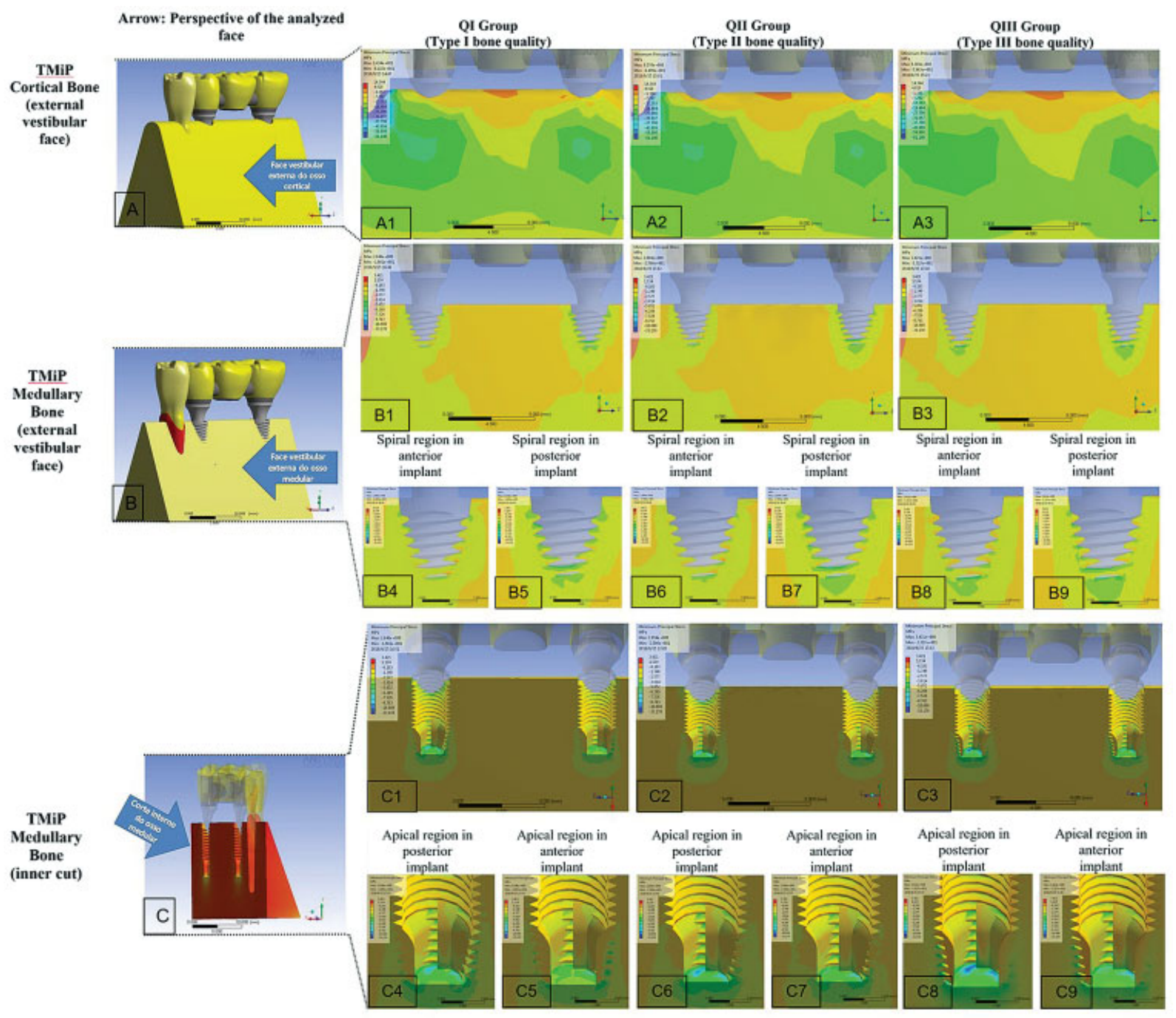

Fig. 2 Set of images of TMiP bone analysis, (A) external vestibular cortical, A1: type I bone, A2: type II bone, A3: type III bone; (B) external vestibular medullary, B1: type I bone, B2: type II bone, B3: type III bone, B4: spiral region in anterior implant in type I bone, B5: spiral region in posterior implant in type I bone, B6: spiral region in anterior implant in type II bone, B7: spiral region in posterior implant in type II bone, B8: spiral region in anterior implant in type III bone, B9: spiral region in posterior implant in type III bone; (C) medullary inner cut, C1: type I bone, C2: type II bone, C3: type III bone, C4: spiral region in posterior implant in type I bone, C5: spiral region in anterior implant in type I bone, C6: spiral region in posterior implant in type II bone, C7: spiral region in anterior implant in type II bone, C8: spiral region in posterior implant in type III bone, C9: spiral region in anterior implant in type III bone.

stress in the medullary bone. In a situation where cortical bone of lower stiffness and quality (QIII) is found, it concentrates lower stress, and in contrast, higher stress is generated in the medullary bone, since the "protective" effect is partially reduced. Therefore, as stated by Papavasiliou et al, ${ }^{28}$ the presence of a considerable layer of cortical bone is clinically fundamental to avoid undue stress to the medullary bone.

In the cortical bone, when compared with all the simulated bone types (I, II, or III), the maximum value obtained in the QI group ( $45 \mathrm{MPa})$ was still far from the value considered critical in the literature $(\sim 170 \mathrm{MPa})^{10,28-32}$; thus, considering the literature values, this higher TMiP would not pose risks to its physiological limits.

In the cervical transition between cortical and medullary bones, higher stresses were observed as bone density decreased. An interesting fact that may be related to the clinically observed saucerization. As one of the reasons reported in the literature, the eventual overload may lead to the loss of osseointegration. ${ }^{33-35}$ As stated in a study by Linetskiy et $\mathrm{al}^{30}$ medullary bone has a lower elasticity modulus and consequently a lower maximum tolerance limit to deformation. This represents an area of higher fragility for eventual osseointegration loss and shorter implant survival and corroborates the study by Ichikawa et al and Demenko et al, ${ }^{36,37}$ who state that the low bone density of medullary bones (type III or IV) increases bone stress and concomitantly decreases implant stability.

Regarding the stress in medullary bone, there was variation within a significance and importance scale with possible clinical reflexes, since the literature reports transition reference values of elastic to plastic deformation of approximately $10 \mathrm{MPa} .{ }^{29-32}$ In this study, there was variation among $7 \mathrm{MPa}$ (type I bone, group QI), $10 \mathrm{MPa}$ (type II bone, group QII), and $20 \mathrm{MPa}$ or more (type III bone, group QIII). In the medullary 
bones of groups QII and QIII, major stresses were already beginning to appear in the periapical region of the most posterior implant, especially in the group simulating type III bone, with bone stress area above $10 \mathrm{MPa}$ (dark blue region). It is noticeable that in the latter situation of poorer bone, according to the present simulation, there could already be biomechanical damage to the bone behavior due to stress overload, which could translate clinically into eventual resorption or loss of osseointegration.

Clinically, the area with such cited stresses represents a risk of injury, because it has exceeded the physiological bone tolerance limit. Therefore, in situations such as this one, special care is essential to avoid any problems. As noted in the literature, occlusal load control, for example, may be a precautionary approach in prostheses with lower implant support (pontic prosthesis) that is inserted into poor quality bone. $7,30,38,39$

In general, the bone surrounding the most posterior implant has always been the most stressed, either in the region of the implant turns (-Fig. 2-B5, B7, and B9) or in the apical region (-Fig. 2-C4, C6, and C8). A possible explanation may be the size of the occlusal face in addition to the load applied to the molar surface, which are evidence indicating the importance of control and constant occlusal attention, especially in regions that are more likely to receive a high masticatory incidence.

This study corroborates the study by Linetskiy et al and Misch et $a l,{ }^{7,30}$ who claim that one of the major causes of bone loss is periimplantitis (which involves inflammatory factors), implant overload (mechanical factors), and poor bone quality and inadequate implant size. According to these authors, with bone loss, both the quality of the bone and the size of the implant influenced its lifetime. The success of the implant over a long period depends on the adequate maintenance of the stress developed within safe physiological limits. ${ }^{30}$

Further studies are necessary to examine possible alternatives to decrease the stresses in low quality bone and to verify, for example, the viability and effectiveness of varying the occlusal loads in the prostheses, implant diameters, or material and infrastructure types.

\section{Conclusion}

Considering the limitations of this study, it can be affirmed that there are divergences in the behavior of the bone tissues analyzed in terms of the use of a fixed pontic partial prosthesis on two regular implants in the different bone qualities studied. There was disparity in stress when comparing type I, II, and III bone qualities, which reveals the need for clinical attention regarding the bone density into which implants are rehabilitated. Under the conditions and characteristics studied, the presence of type III medullary bone requires attention to the apical region of the posterior implant. Therefore, such a situation requires specific adjustments and care to avoid further complications.
Conflict of Interest

None declared.

\section{Acknowledgments}

The researchers involved in this project appreciate the incentives provided by the University of Rio Verde (UniRV) and National Council for Technological and Scientific Development (CNPq).

\section{References}

1 Kenney R, Richards MW. Photoelastic stress patterns produced by implant-retained overdentures. J Prosthet Dent 1998;80(05): 559-564

2 Chen XY, Zhang CY, Nie EM, Zhang MC. Treatment planning of implants when 3 mandibular posterior teeth are missing: a 3dimensional finite element analysis. Implant Dent 2012;21(04): 340-343

3 Corrêa CB, Margonar R, Noritomi PY, Vaz LG. Mechanical behavior of dental implants in different positions in the rehabilitation of the anterior maxilla. J Prosthet Dent 2014;111(04):301-309

4 Misch CE, Suzuki JB, Misch-Dietsh FM, Bidez MW. A positive correlation between occlusal trauma and peri-implant bone loss: literature support. Implant Dent 2005;14(02):108-116

5 Iplikçioğlu H, Akça K. Comparative evaluation of the effect of diameter, length and number of implants supporting three-unit fixed partial prostheses on stress distribution in the bone. J Dent 2002;30(01):41-46

6 Esposito M, Hirsch JM, Lekholm U, Thomsen P. Biological factors contributing to failures of osseointegrated oral implants. (II). Etiopathogenesis. Eur J Oral Sci 1998;106(03):721-764

7 Misch CE, Perel ML, Wang HL, et al. Implant success, survival, and failure: the International Congress of Oral Implantologists (ICOI) Pisa Consensus Conference. Implant Dent 2008;17(01):5-15

8 von Stein-Lausnitz M, Nickenig HJ, Wolfart S, et al. Survival rates and complication behaviour of tooth implant-supported, fixed dental prostheses: a systematic review and meta-analysis. J Dent 2019;88:103167

9 Morton D, Gallucci G, Lin WS, et al. Group 2 ITI Consensus Report: Prosthodontics and implant dentistry. Clin Oral Implants Res 2018;29(Suppl 16):215-223

10 Pellizzer EP, Lemos CAA, Almeida DAF, de Souza Batista VE, Santiago Júnior JF, Verri FR. Biomechanical analysis of different implant-abutments interfaces in different bone types: An in silico analysis. Mater Sci Eng C 2018;90:645-650

11 Cinar D, Imirzalioglu P. The effect of three different crown heights and two different bone types on implants placed in the posterior maxilla: three-dimensional finite element analysis. Int J Oral Maxillofac Implants 2016;31(02):e1-e10

12 Santiago Junior JF, Verri FR, Almeida DAF, de Souza Batista VE, Lemos CAA, Pellizzer EP. Finite element analysis on influence of implant surface treatments, connection and bone types. Mater Sci Eng C 2016;63:292-300

13 Misch CE. Bone density: a key determinant for treatment. Planning In: Misch CE. Contemporary Implant Dentistry. 3rd ed. St. Louis: Mosby; 2007:130-146

14 Santiago RC, Vitral RWF. Métodos de avaliação da densidade mineral óssea e seu emprego na Odontologia. Pesq Bras Odontoped Clin Integr 2006;6:289-294

15 Bonnick SL, Shulman L. Monitoring osteoporosis therapy: bone mineral density, bone turnover markers, or both? Am J Med 2006; 119(04, Suppl 1):S25-S31

16 Van Staden RC, Guan H, Loo YC. Application of the finite element method in dental implant research. Comput Methods Biomech Biomed Engin 2006;9(04):257-270 
17 Trisi P, Rao W. Bone classification: clinical-histomorphometric comparison. Clin Oral Implants Res 1999;10(01):1-7

18 Black J, Hastings G. Handbook of Biomaterial Properties. London: Chapman \& Hall Publ.; 1998:3-23

19 Zienkiewicz OC, Taylor RL. The Finite Element Method. 6th ed, Vol. 1 Oxford: Butterworth-Heinemann; 2005:164-199

20 Toniollo MB, Macedo AP, Rodrigues RCS, Ribeiro RF, Mattos MdaG. Three-dimensional finite element analysis of the stress distribution on morse taper implants surface. J Prosthodont Res 2013;57 (03):206-212

21 Nizo PT. Avaliação das tensões e deformações do osso cortical mandibular sob ação do músculo pterigoideo lateral pela análise de elementos finitos. Monografia de Graduação. Piracicaba, Brazil: Faculdade de Odontologia de Piracicaba - UNICAMP; 2013:25

22 Fonseca LGEstudo comparativo de três tipos de implantes curtos: análise pelo método dos elementos finitos 3D. Dissertação de Mestrado, Faculdade de Odontologia da Pontifícia Universidade Católica de Minas Gerais. Belo Horizonte2008:62

23 Ona M, Wakabayashi N. Influence of alveolar support on stress in periodontal structures. J Dent Res 2006;85(12):1087-1091

24 Schwartz-Dabney CL, Dechow PC. Variations in cortical material properties throughout the human dentate mandible. Am J Phys Anthropol 2003;120(03):252-277

25 Sevimay M, Turhan F, Kiliçarslan MA, Eskitascioglu G. Threedimensional finite element analysis of the effect of different bone quality on stress distribution in an implant-supported crown. J Prosthet Dent 2005;93(03):227-234

26 Rodriguez XC, et al. Biomechanical repercussions of bone resorption related to biologic width: a finite element analysis of three implant-abutment con-figurations. Int J Periodont Restor Dent 2009;29:479-487

27 Meriç G, Erkmen E, Kurt A, Tunç Y, Eser A. Influence of prosthesis type and material on the stress distribution in bone around implants: a 3dimensional finite element analysis. J Dent Sci 2011;6:25-32

28 Papavasiliou G, Kamposiora P, Bayne SC, Felton DA. Three-dimensional finite element analysis of stress-distribution around single tooth implants as a function of bony support, prosthesis type, and loading during function. J Prosthet Dent 1996;76(06):633-640

29 Toniollo MB, Macedo AP, Pupim D, Zaparolli D, Mattos MGC. Finite element analysis of bone stress in the posterior mandible using regular and short implants, in the same context, with splinted and non-splinted prostheses. Int J Oral Maxillofac Implants 2017; 32:199-206

30 Linetskiy I, Demenko V, Linetska L, Yefremov O. Impact of annual bone loss and different bone quality on dental implant success - A finite element study. Comput Biol Med 2017;91:318-325

31 Teixeira MF, Ramalho SA, de Mattias Sartori IA, Lehmann RB. Finite element analysis of 2 immediate loading systems in edentulous mandible: rigid and semirigid splinting of implants. Implant Dent 2010;19(01):39-49

32 Frost HMA. A 2003 update of bone physiology and Wolff's Law for clinicians. Angle Orthod 2004;74(01):3-15

33 Lu YJ, Chang SH, Ye JT, Ye YS, Yu YS. Finite element analysis of bone stress around microimplants of different diameters and lengths with application of a single or composite torque force. PLoS One 2015;10:1-9

34 Hudieb MI, Wakabayashi N, Kasugai S. Magnitude and direction of mechanical stress at the osseointegrated interface of the microthread implant. J Periodontol 2011;82(07):1061-1070

35 Berglundh T, Abrahamsson I, Lindhe J. Bone reactions to longstanding functional load at implants: an experimental study in dogs. J Clin Periodontol 2005;32(09):925-932

36 Ichikawa T, Kanitani H, Wigianto R, Kawamoto N, Matsumoto N. Influence of bone quality on the stress distribution. An in vitro experiment. Clin Oral Implants Res 1997;8(01):18-22

37 Demenko V, Linetsky I, Nesvit V, Linetska L, Shevchenko A. FE study of bone quality effect on load-carrying ability of dental implants. Comput Methods Biomech Biomed Engin 2014;17(16): 1751-1761

38 Yusuke U, Shinichiro K, Takayoshi N, et al. Effects of Mechanical Repetitive Load on Bone Quality Around Implants in Rat Maxillae. Yamadaoka, Suita-city, Osaka, Japan: Department of Applied Prosthodontics, Graduate School of Biomedical Sciences, Nagasaki University, Nagasaki, Japan, Division of Materials and Manufacturing Science, Graduate School of Engineering, Osaka University; 2017:8

39 O'Mahony AM, Williams JL, Spencer P. Anisotropic elasticity of cortical and cancellous bone in the posterior mandible increases peri-implant stress and strain under oblique loading. Clin Oral Implants Res 2001;12(06):648-657 